\title{
Non Accession to UNCLOS and the Doctrine of Innocent Passage or Transit Passage: Challenges and Prospects
}

\author{
Md. Asrafuzzaman Babu* \\ Lecturer, Department of Law, North Western University, Khulna, Bangladesh
}

*Corresponding Author: Md. Asrafuzzaman Babu, Lecturer, Department of Law, North Western University, Khulna, Bangladesh

\begin{abstract}
United Nation Convention on Law of the Sea (UNCLOS) regime is the compromise between costal and the shipping states interests. It is framework conventions and which is binding on the member states subject to the enactment of national legislation. It is the reflection of existing customary law and also the compromise interest of the member states. UNCLOS regime has been challenged by some non-member coastal states in some cases moved beyond the permissible scope of regulation over the territorial sea and strait in terms of granting innocent passage right. Article 33 of VCLT outlines the nature of treaty obligation for non-member states.
\end{abstract}

Keywords: UNCLOS, Innocent Passage, Transit, Treaty, International Law

\section{INTRODUCTION}

The traditional concept of innocent passage in the territorial sea or the traditional freedom of navigation in the high sea has been transformed to the freedom of transit in the straits. UNCLOS 1982 introduced the transit right in the straits and allowed a balanced right between freedom of navigation and the innocent passage right. Many bordering non-member states accepted the principles of UNCLOS regulating the innocent passage and transit rights and some others vigorously opposed it and enacted different legislations according to their own national interests. It poses difficult challenges to UNCLOS and the purpose of the present study will be to see whether the variant practice of the coastal states is compatible with international law or not. The paper seeks to shed brief light on the conflicting claims of different states on international straits. The counter claim of U.S. and Iran on the Strait of Hormuz will be taken in picture and lastly it offers some probable solutions.

\section{Methodology OF THE STUdY}

In dealing with these issues, both primary and secondary sources will be required to review. Pertinent treaties, Conventions, Statutes, Case-laws, will be brought into picture to look at from a scrutinize views. Those primary sources are the core of this research.

Secondly, since there are gaps and complexity in the existing literatures relating to the topics, germane secondary sources including books, journals, articles, online resources, statements, presented papers, documents of relevant international and non-governmental organizations and other materials will be taken into account for proper analysis, comprehensive understanding and consistent conclusion.

In conducting legal research, one has to depend on documentary sources information that already exists in some form e.g. journal articles, case reports, legislation treaties, historical records. The analysis and findings will be conducted by going through all pertinent materials. As the research will be based on documentary sources, it will be doctrinal one.

\section{The InNOCENT PASSAGE UNDER INTERNATIONAL LAW}

For centuries, nations have abided by the concept of innocent passage, which allows nations to use foreign territorial waters for navigational purposes. ${ }^{1}$ Innocent passage exists in order to reconcile the

\footnotetext{
${ }^{1}$ Matt Roston, 'The Northwest Passage's Emergence As An International Highway' (2008-2009) 15 Sw. J. Int'1 L. 449 
freedom of ocean navigation with the theory of territorial waters. ${ }^{2}$ The right of innocent passage has been recognized as a principle of customary international law ${ }^{3}$ since the Geneva Convention on the High Seas was enacted in $1958 .{ }^{4}$ Innocent passage is defined as navigation through the territorial sea that is not prejudicial to the coastal state. ${ }^{5}$ Innocent passage has a strong foundation in international maritime law. ${ }^{6}$ The status of vessel and the question of reciprocity were the main factor to grant such rights. ${ }^{7}$ Two factors which traced back to the promotion of the concept of the innocent passage. The first and foremost is the state practice and the second is the decisions of the municipals courts. ${ }^{8}$

However, to understand that right further, it is necessary to clarify the meaning of "innocent passage." International law scholars have debated over the meaning of the word "innocent." ${ }^{9}$ While scholars have attempted to define the term in an objective manner, subjective interpretation by the coastal state also often defines the meaning of "innocent. Generally, if a ship does not harm the interests of the coastal state during or by its sail through the territorial water, then the passage is deemed innocent. Passage means to navigate through the territorial water without having contacts with the territory of the coastal state. Stopping or anchoring pursuant to ordinary navigation, or because of danger or distress, does not discontinue the ship's passage. ${ }^{10}$

The question of innocence received full discussion in Corfu Channel case, where the court referred about the manner of the passage and it has given an objective determination to consider a passage as innocent. ${ }^{11}$ Later the ILC draft, Lautherpact and Fitzmaurice differed slightly from the objective criterion to determine a passage innocent and finally a compromise reached in 1958 convention. ${ }^{12}$ The 1982 convention adheres to the basic concept of the 1958 convention. ${ }^{13}$ Later it has provided a list when the passage ceases to be innocent. ${ }^{14}$

\section{THE Right OF TRANSIT IN INTERNATIONAL STRAITS}

The regime of transit passage in international straits was shaped by several interrelated factors and developments in the law of the sea: the expansion of territorial seas to twelve miles, the distinction between the right of innocent passage and high seas freedom of navigation. ${ }^{15}$

The right of warships to enjoy navigational freedoms while transiting through an international strait has been largely unchallenged for centuries. This is primarily because the coastal states that border on international straits have historically claimed only a $3 \mathrm{~nm}$ territorial sea. ${ }^{16}$ Since almost all strategic international straits are wider than $6 \mathrm{~nm}$, warships could transit using the corridor of high seas in the middle of the strait without entering the territorial waters of the coastal states. Thus, "the ships and aircraft of all nations had the uncontested right to pass through such strategically important straits as Gibraltar, Hormuz, Bab el Mandeb, Lombok and Malacca, regardless of the political unpopularity of

\footnotetext{
${ }^{2}$ Phillip C. Jessup, The Law Of International Waters And Maritime Jurisdiction(1927) G.A. Jennings Co 120

${ }^{3}$ J.G. Starke, Introduction to International Law 38 (London Butterworths $9^{\text {th }}$ ed. (1984)

${ }^{4}$ Convention on the High Sea (adopted 29 April 1958 and came into force 30 September 1962) 450 U.N.T.S. 11

${ }^{5}$ Ibid,

${ }^{6}$ George P. Smith Ii, Restricting The Concept of Free Seas: Modern MaritimeLaw Evaluate (1980) 37

${ }^{7}$ Donald R Rothwell and Tim Stephens, The International Law of the Sea (Oxford/Portland, Orgeon; Hart Publishing 2010) 206- 209

${ }^{8}$ John Basset Moore, A Digest of International Law vol.1 Washington, Government Printing Office (1906) 720721

${ }^{9}$ Francis Ngantcha, The Right Of Innocent Passage And The Evolution Of The International Law of The Sea: The Current Regime of Free Navigation In Coastal Waters Of Third States (1990)

${ }^{10}$ Ibid 52-54

${ }^{11}$ Corfu Channel Case (UK v Albania) (Merits) [1949] ICJ Rep 430

12 Convention on the Territorial Sea and the Contiguous Zone (adopted 29 April 1958 entered into force 10 September 1964) United Nations, Treaty Series, vol. 516 art 14.4

${ }^{13}$ UNCLOS, art19.1

${ }^{14}$ Ibid art 19.2

${ }^{15}$ Morris F. Maduro, Passage Through International Straits: The Prospects Emerging From The Third United Nations Conference On The La W Of The (1980)

${ }^{16}$ Tommy T. B. Koh, "Negotiating a New World Order for the Sea," Virginia Journal of International Law, Vol. 24, No. 4 (1984), pp. 762-763.
} 
their mission.. ${ }^{17}$ UNCLOS 1982 confirmed breadth of the territorial sea up to 12 nautical miles ${ }^{18}$ and which has changed the previous scenario of transit passage right in straits. It has introduced transit right and added some new rights with the previous right of innocent passage. ${ }^{19}$ It has also confirmed that state cannot suspend the transit right and even if state can then the power of suspension is very limited.

\section{The Conflict Between InNocent Passage And Transit Right}

The right of innocent passage has been recognized as a customary principle of international law. There is no ambiguity regarding innocent passage right either in territorial sea or international straits. On the contrary the status of transit right is still ambiguous in state practice. Unanimity is lacking in granting transit right which has been given under UNCLOS 1882. Here the root matter of conflict is related with over flight and under water passage which is beyond innocent passage. The right of innocent passage excludes these two rights of foreign states and where the transit right includes these. There are lots of disagreements among member and non-member states regarding the status of transit right. Some see it solely as quid pro que where some other as a matter of customary law. There are about 125 international straits and where 42 straits are being considered important for world trade. The disagreement of bordering states in granting innocent passage or transit right hampers the world economy. The world witnessed the Tanker War from 1984 to 1987 between USA and Iran related with the transit issue in the Strait of Hormuz.It is crucial to shed light on the applicable law to international transit beyond the treaty law because there are many bordering sates that are not party to UNCLOS.

Ships of all nations enjoy the right of innocent passage through the territorial sea. ${ }^{20}$ On the other hand, coastal States have broad and durable security interests in the territorial sea, and they may prescribe and enforce laws that condition or preclude altogether the surface transit of foreign warships. In most circumstances, innocent passage can be suspended by the coastal State; transit passage cannot be suspended. Transit passage also allows submerged transit and over flight of aircraft through the strait. ${ }^{21}$ Only surface transits are permitted for ships engaged in innocent passage.

In the absence of acceptance of UNCLOS, however, non-member States cannot use these clear rules as a guide and therefore to dissolve the disputes they must revert to the customary principles of international law.

\section{TRANSit PASSAGE AND CUSTOMARY INTERNATIONAL LAW}

Most of the writers talked about the relationship between transit right and customary principle before the adoption of UNCLOS ${ }^{22}$. Only a few American authors argue in favor of the customary norm after UNCLOS. ${ }^{23}$ At the opposite some believe that UNCLOS's provision on transit passage have not yet become established in customary law. ${ }^{24}$ This is the position of Scovazzi, who in 1995 argued that the UNCLOS transit passage regime contains new provisions that have yet to be confirmed as customary international law. A significant number of states appear reluctant either explicitly or impliedly to accept either transit passage regime as a whole or some of its implications. ${ }^{25}$ Caminos, writing in 1987 after reviewing state practice expressed a similar view, while state practice does not clearly present a pattern reflective of generally accepted legal norm, rather it can be said that the practice of states denote the emerging norm of customary law. ${ }^{26}$ Again the straits regime is largely technical in nature

\footnotetext{
${ }^{17}$ The Hague Convention of 1930 Koh, "Negotiating a New World Order for the Sea', id 762-764

${ }^{18}$ UNCLOS,Article 3

${ }^{19}$ Ibid, Article 38.2

${ }^{20}$ Ibid Art17

${ }^{21}$ ibid, Art. 38(1)-(2).

${ }^{22}$ Hugo Caminos, Vincent P, The Legal Regime of Straits: Contemporary Challenges and Solutions, Cambridge university press, (2014)

${ }^{23}$ B. B. Jia, The Regime of Straits in international law, Clarendon Press, Oxford, (1998) 206207

${ }^{24}$ R. R. Churchill \& A.V. Lowe, Law of The Sea3rd edits. ( Manchester University Press, 1999) 94

${ }^{25}$ T. Scovazzi, 'Management Regimes and Responsibility for International Straits: With Special Reference to the Mediterranean Straits', (1995) 19 Marine Policy 144

${ }^{26}$ H. Caminos, 'The Legal Regime of Straits in the 1982 United Nations Convention on the Law of the Sea', (1987) 205 Recueil des course, 231232
} 
and customary law cannot express details and shades of meaning that are only within the reach of conventional rules. ${ }^{27}$

The vast majority of states whose interests are specially affected by the right of transit passage, that is bordering states and the user states and they are now parties to the UNCLOS. Among them are Australia, Bahamas, Canada, China, Denmark, Djibouti, France, Greece, Honduras, Indonesia, Italy, Japan, The Republic of Korea, Liberia, Malaysia, Morocco, Oman, Panama, Philippines, The Russian Federation, Singapore, Spain, Sweden, UK and Yemen. In order to examine the state practice some proposed to check the domestic piece of legislations, declarations, bilateral and multilateral agreement. ${ }^{28}$ Treves distinguishes between the practice of states that consider transit as a customary norm (UK, France USA, USSR, Australia and Papua New Guinea) and those that are in favor of innocent passage right in straits. ${ }^{29}$ These countries implement transit right as a matter of customary law. At other hand there are a larger number of groups who consider it solely as a matter of conventional right. The practice of Chile, Denmark, Egypt, Greece, Iran, Indonesian, Italy, Japan, Republic of Korea, Malaysia, Netherlands, Oman and Spain is notable here. ${ }^{30}$ Many states even who are parties to the convention omit the reference to the right of passage and even in some cases states allowed innocent passage right subject to prior notifications for warships, nuclear power ships and ships carrying hazardous substances.

Iran and United States profoundly disagree about the applicable international law in the Strait of Hormuz. This is the locus of conflict between these two countries. The standpoint is complicated because both the countries did not become the member of UNCLOS. Both the countries have their own stand regarding the applicable law.

\subsection{Iran's Position}

Tehran asserts that the navigational regime of transit passage through straits used for international navigation is solely a feature of UNCLOS, and therefore the privilege of transit passage is unavailable to non-parties. Iran maintains that the careful balance of rights and duties reflected in UNCLOS are available only as a specific condition of agreement of the package deal. Since the regime of transit passage is a quid pro quo for acceptance of other terms of the treaty, states not party to UNCLOS, such as the United States, are not entitled to exercise transit passage in the Strait of Hormuz. To permit the United States to enjoy transit passage is to indulge Washington in the very type of "cherry picking" among the provisions of UNCLOS that the package deal was designed to prevent. The regime of transit passage is reserved only for parties to UNCLOS.

In a television interview in 2008, Hoseyn Panahi-Azar, the director general of the legal and international affairs department of the Iranian Foreign Ministry, stated that the regime of innocent passage applies to U.S. warship transits in the Strait of Hormuz. Transit through the Strait may not be suspended, he acknowledged, but Iran was entitled to impose certain limitations based on their own laws [even] for transit passage. ${ }^{31}$ The ships which are registered in the member states of the convention are entitled to invoke contractual rights of UNCLOS. ${ }^{32}$

Therefore if any military vessels enter Iranian waters without permission even if they are passing innocently it has violated the Iranian law. In addition, innocent passage has certain conditions and some of these vessels do not meet these conditions. They should not carry any potential threat against the costal countries. ${ }^{33}$

\footnotetext{
${ }^{27}$ Supra note 22

${ }^{28}$ Supra note 26 at 206

${ }^{29}$ Treves, 'Codification du droit international et pratique des Etats le Droit de la mer, (1990) Recueil des cours 133 ' the USSR is less supportive to ensure transit right in territorial sea

${ }^{30}$ Nihan Unlu, The Legal Regime of the Turkish Straits (Martinus Nijhoff Publications, 2002) 75 available at https://books.google.co.in/books?id visited 10 December 2018

31 Vision of the Islamic Republic of Iran Network 2, Tehran, in Persian, Jan. 12, 2008, verbatim transcript translated in Iran TV discussion on Strait of Hormuz Incident, BBC Worldwide Monitoring Middle EastPolitical, January 13, 2008

32 ibid

${ }^{33}$ ibid
} 
Iran further argued that, article $38(1)^{34}$ affords all ships and aircraft the right of transit passage, it is doubtful that this phrase captures ships and aircraft of non-parties. Article 36(1) of the Vienna Convention on the Law of Treaties requires that provision of treaty rights to third states arise only in the case in which treaty parties intended the provisions to accord those rights. ${ }^{35}$ There is no evidence that the drafters of the Third United Nations Conference contemplated according such rights to nonparties. Tehran offered article 34 of the 1969 Vienna Convention on the Law of Treaties in support of its statement ${ }^{36}$. The provision states that only parties to a treaty are entitled to benefit from the contractual rights created therein. Third parties inure no rights under a treaty, unless those are specifically set forth by the terms of the agreement.

If that is the case, then Iran advocates the regime of innocent passage applies to the United States in the Strait of Hormuz, and the regime is derived not from UNCLOS but based upon customary international law, the 1958 Convention, and the Corfu Channel Case. Iran's declaration made upon signature of UNCLOS in 1982 preserves the country's prerogatives on the Strait of Hormuz, at least until such time as UNCLOS is universally accepted.

\subsection{The U.S. Position}

Since the United States is not party to UNCLOS, it does not automatically enjoy the right of transit passage through straits used for international navigation if the coastal state also is not a party to the treaty. The United States counters that although the regime of transit passage through straits used for international navigation is reflected in UNCLOS, it springs from customary international law, rather than being a creation of the terms of the treaty. Although transit passage is codified in article $38^{37}$ of UNCLOS, it merely reflects long-standing state practice and opinio juris. Even though the United States is not a party to UNCLOS, therefore, it nonetheless enjoys the right of transit passage through international straits as a matter of historical practice and a history of legal obligation among states. To put a final point on it, the United States rejects Iran's claim of broad security competence over the territorial sea, since even article $16(4)^{38}$ of the 1958 Territorial Sea Convention precludes the coastal State from suspending innocent passage.

The United States protested Iran's position on several occasions.Near the end of the Third United Nations Conference on the Law of theSea, the United States left nothing to chance, and made a statement todrive home the point that coastal states may not condition innocent passageof warships on prior notification or consent. ${ }^{39}$

Although the United States has not signed UNCLOS, ${ }^{40}$ the Senate Foreign Relations Committee prepared a report on the treaty in 2007. The report contains U.S. understandings related to transit passage:

- All ships and aircraft, including warships and military aircraft, regardless of, for example, cargo, armament, means of propulsion, flag, origin, destination, or purpose, are entitled to transit passage and archipelagic sea lanes passage in their normal mode

- Normalmodeincludes, inter alia

$>$ Submerged transit of submarines;

\footnotetext{
${ }^{34}$ Supra note 34

${ }^{35}$ Vienna Convention on the Law of Treaties(adopted 23 May 1969 entered into force 27 Jan 1980 )

${ }^{36}$ Ibid art 34

${ }^{37}$ Supra note 12

${ }^{38}$ Ibid art 16.4

${ }^{39}$ IMO Doc. A/CONF.62/WS/37 and Add.1-2, Mar. 8, 1983, reprinted in XVII Official Records Of The Third United Nations Conference on The Law of The Sea (Plenary Meetings, Summary Records and Verbatim Records, as well as Documents of the Conference, Resumed Eleventh Session and Final Part Eleventh Session and Conclusion), at 243.

${ }^{40}$ President William J. Clinton signed the Agreement relating to the Implementation of Part XI of the United Nations Convention on the Law of the Sea of 10 December 1982 on July 29, 1994 and submitted the Convention and Agreement to the U.S. Senate for the first time on October 7, 1994, S. Treaty Doc. No. 103-39 (1994)
} 
Non Accession to UNCLOS and the Doctrine of Innocent Passage or Transit Passage: Challenges and Prospects

$>$ Over flight by military aircraft, including in military formation;

$>$ Activities necessary for the security of surface warships, such as formation steaming and other force protection measures;

$>$ Underway replenishment and

$>$ The launching and recovery of aircraft. ${ }^{41}$

\section{The Applicable Principles and Probable Solutions}

The transit regime in the strait is purely a creation of treaty law. The right is normally unavailable to the non-parties. To invoke transit right the establishment of treaty or as customary international law is important. Till now no member states went before ICJ asking the clarity of the status. Experience in the Oil Platforms Case demonstrates that Iran is unafraid to bring suit at the International Court of Justice against the United States to challenge the legality of U.S. Warship operations near its coast. ${ }^{42}$ Both Iran and the United States insist the law is on their side. Is the United States correct in its claim that transit passage has entered into customary law? Certainly, the centuries of experience with peacetime deployment of warships attest that their movement through straits is "quite common, generally unnoticed and usually without attendant controversy." passageways on innumerable occasions, so the idea of their closure as a matter of law is relatively new.

Although freedom of navigation was exercised in straits used for international navigation, it was done within the framework of the three nautical mile territorial sea. Transit passage, however, is both a greater and a lesser right than what existed for maritime powers in centuries past. It is a greater right because it dispenses with the obstacle of coastal State maritime boundaries to transit the strait. Under transit passage, ships, aircraft, and submarines are no longer bound by the limitation of avoiding a coastal State's territorial sea, and may move through the strait on any track shoreline- to-shoreline. Analyzing all these controversies the following points can be drawn to resolve the dispute among nonmember states (Iran vs. U.S).

Firstly, Iran may insist to enjoy only non-suspend able innocent passage evolved from as a matter of customary international law from Corfu Channel Case through those parts of the straits of Hormuz overlapped by its three nautical miles. In other way USA is correct as a matter of customary law that ships, warships, aircraft, and submarines would enjoy high seas freedom beyond Iran's three nautical mile of territorial sea.

Secondly, the average breadth of international straits is 16 nautical miles so the area remains beyond traditional claim of territorial sea is almost 10 nautical miles and where foreign ships will get traditional freedom of navigation. Here as the Hormuz channel is 20 miles in wide, area over which Iran could exercise sovereignty and other require innocent passage is very limited. The practical upshot is that US ships aircraft irrespective any manner would exercise high sea freedom beyond three nautical miles of Iran claim.

Thirdly, the duration of recognition of innocent passage right by ICJ in 1949 and Geneva Convention in 1958 through straits for all ships irrespective of merchant or warships should be viewed from historical perspectives. That time the territorial sea was only three nautical miles and aircrafts were not used as regular part of business transactions. So the omission of over flight and under water passage was not surprising. ${ }^{44}$

Fourthly, it is still doubtful whether the transit right is considered as customary norms. It can be perfectly true for all kinds of merchant ships not for warships, over flight and under water passage.

\footnotetext{
${ }^{41}$ Sec. 3(3), Convention on the Law of the Sea, Senate Foreign Relations Committee Rpt. 110-9 Dec. 19, 2007 at 20.

${ }^{42}$ Oil Platforms (Iran v. United States) (Merits) [2003] I.C.J

${ }^{43}$ William T. Burke, Who Goes Where, 'When, and How: International Law of the Sea for Transportation' (Restructuring Ocean Regimes: Implications of the Third United Nations Conference on the Law of the Sea), (1977) 31 INT'L ORG 267 270-71

${ }^{44}$ Supra note 24 at 111
} 
Most probably it can be true in case of Strait of Dover and Gibraltar where all bordering states explicitly granted such rights to all countries.

Fifthly, If Iran claims only a three nautical mile territorial sea, and then it seems reasonable that it could expect other states to honor the corresponding regime of innocent passage through the territorial sea. Iran also must expect, however, that states will exercise the full panoply of high seas freedoms and other internationally lawful uses of the sea outside of three nautical miles.

On the other hand, Iran's current claim of a 12 nautical mile territorial sea suggests that other nations are entitled to exercise freedom of navigation through the strait, either in transit passage or the historic antecedent of high seas freedoms, which is even more permissive. Instead, Iran has sought to preserve the navigational regime of innocent passage through the strait, while at the same time incorporating the contemporary 12 nautical mile territorial sea. The Third United Nations Conference on the Law of the Sea rejected that outcome as a risk that dissembles the bargain of the package deal with cafeteriastyle selection and rejection of legal provisions, and this practice has no basis in treaty or customary law.

\section{CONCLusions}

The transit regime came out from the UNCLOS 111 is still merely a treaty norm and it can be considered as a customary norm at any point of future time, which will depend on the long standing practice of states and the opinion Juris. However no practice, opinio juris can be established when lack of uniformity exists. There is a group of sates who consider it as a customary norm, some other put some preconditions to invoke this right, and the rest part countries are persistently objecting to the acceptance of the rule. It remains ambiguous and these ambiguities are inimical to the development and stabilization of rule of custom. The right of over flight and under water passage has been accepted as a customary rule in EEZ and High Sea but same is not true in Straits.Some scholars suggest the regime of transit passage has entered into customary international law not as a general right, perhaps, but at least for some particularly important straits. The crystallization into customary law of rights akin to transit passage, however, is inseparable from the general right of a 12 nautical mile territorial sea. To put it another way, coastal States that claim a 12 mile territorial sea as a feature of customary law cannot also reject the corresponding right of transit passage (or even a continuation of high seas freedoms) in the same strait.

\section{REFERENCES}

\section{Primary Sources}

\section{Conventions}

[1] Convention on the High Sea (adopted 29 April 1958)

[2] Convention on the Territorial Sea and the Contiguous Zone (adopted 29 April 1958)

[3] United Nation Convention on Law of the Sea (UNCLOS), 1982.

[4] The Hague Convention of 1930.

[5] Vienna Convention on the Law of Treaties (adopted 23 May 1969).

Cases

[6] Corfu Channel Case (UK v Albania) (Merits) [1949] ICJ

[7] Oil Platforms (Iran v. United States) (Merits) [2003] I.C.J

\section{Secondary Sources}

\section{Referred Books}

[8] J.G. Starke, Introduction to International Law, London Butterworths, 9thed. (1984)

[9] Donald R Rothwell and Tim Stephens, The International Law of the Sea , Oxford Publishing (2010)

[10] Hugo Caminos, Vincent P, The Legal Regime of Straits: Contemporary Challenges and Solutions, Cambridge university press(2014)

[11] B. B. Jia, The Regime of Straits in international law, Clarendon Press, Oxford, (1998)

[12] R. R. Churchill and A.V. Lowe, Law of The Sea, Manchester University Press, 3rded.(1999) 


\section{Referred Journals and Articles}

[13] Matt Roston, “The Northwest Passage's Emergence As An International Highway, J. Int'l L, ” (2008)

[14] George P. Smith Ii, "Restricting The Concept of Free Seas: Modern Maritime Law Evaluate" Virginia Journal of International Law, Vol. 24, No. 4(1980)

[15] John Basset Moore, "A Digest of International Law" vol 1 Washington, Government Printing Office (1906)

[16] Francis Ngantcha, "The Right Of Innocent Passage And The Evolution Of The International Law of The Sea" The Current Regime of Free Navigation In Coastal Waters Of Third States (1990)

[17] Tommy T. B. Koh, "Negotiating a New World Order for the Sea" Virginia Journal of International Law, Vol. 24, No. 4 (1984)

[18] H. Caminos, 'The Legal Regime of Straits in the United Nations Convention on the Law of the Sea' (1987)

Citation: Md. Asrafuzzaman Babu. "Non Accession to UNCLOS and the Doctrine of Innocent Passage or Transit Passage: Challenges and Prospects". International Journal of Humanities Social Sciences and Education (IJHSSE), vol 6, no. 3, 2019, pp. 1-8 doi: http://dx.doi.org/10.20431/2349-0381.0603003.

Copyright: (C) 2019 Authors. This is an open-access article distributed under the terms of the Creative Commons Attribution License, which permits unrestricted use, distribution, and reproduction in any medium, provided the original author and source are credited. 